\title{
Betamethasone does not prevent nausea and vomit- ing induced by the dopamine-agonist apomorphine
}

\author{
[La bêtaméthasone ne prévient pas les nausées et les vomissements induits par
} l'agoniste de la dopamine, l'apomorphine]

Patric Axelsson MD, * Sven-Egron Thörn MD PhD, $†$ Åsa Lövqvist RN, $†$ Lisbeth Wattwil RN, $\dagger$ Magnus Wattwil MD PhD†

Purpose: The mechanism of the antiemetic actions of corticosteroids is not known. The purpose of this study was to evaluate if betamethasone can prevent nausea, vomiting or increase of vasopressin induced by apomorphine. Metoclopramide, a dopamine antagonist, was used as a control substance.

Methods: Ten healthy volunteers were studied on three occasions. In a randomized order they were allocated to receive pretreatment with betamethasone $8 \mathrm{mg}$ iv, metoclopramide 10 $\mathrm{mg}$ iv, and normal saline $2 \mathrm{~mL}$ as placebo on the three different occasions, $15 \mathrm{~min}$ before the administration of apomorphine $30 \mu \mathrm{g} \cdot \mathrm{kg}^{-1} \mathrm{sc}$. After administration of apomorphine, episodes of vomiting were recorded, and the intensity of nausea was estimated by the subject on a visual analogue scale (VAS 0-10 $\mathrm{cm})$. Blood samples for analysis of plasma concentrations of vasopressin were analyzed.

Results: One volunteer decided to withdraw, as he experienced akathisia after receiving metoclopramide. During the first two hours after apomorphine, eight of nine volunteers vomited both after betamethasone and placebo. One volunteer did not vomit after betamethasone and placebo but he experienced nausea. None of the volunteers vomited after metoclopramide $(P<0.01$ vs betamethasone and placebo). The maximum VAS for nausea was significantly higher after betamethasone and placebo compared to metoclopramide $(P<0.01)$. The vasopressin levels increased after betamethasone and placebo, but there was no increase in any volunteer after pretreatment with metoclopramide.

Conclusion: This study demonstrates that betamethasone does not prevent nausea, vomiting and increase of vasopressin induced by apomorphine, whereas metoclopramide prevents apomorphine-induced emesis. Our work suggests that betamethasone does not have dopamine-antagonistic effects.
Objectif : Le mécanisme des actions antiémétiques des corticoïdes n'est pas connu. Nous voulions évaluer si la bêtaméthasone peut prévenir les nausées, et les vomissements ou l'augmentation de la vasopressine induits par l'apomorphine. Le métoclopramide, un antagoniste de la dopamine, a été utilisé comme substance témoin.

Méthode : Dix volontaires sains ont été étudiés en trois occasions. Répartis au hasard, ils ont reçu un prétraitement avec 8 $\mathrm{mg}$ de bêtaméthasone iv, $10 \mathrm{mg}$ de métoclopramide iv et $2 \mathrm{~mL}$ de solution salée comme placebo, 15 min avant l'administration de 30 $\mu \mathrm{g} \cdot \mathrm{kg}^{-1}$ d'apomorphine sc. Après l'administration d'apomorphine, les épisodes de vomissements ont été enregistrés et l'intensité des nausées estimée par le sujet sur une échelle visuelle analogique (EVA $0-10 \mathrm{~cm}$ ). Des échantillons sanguins ont été analysés pour les concentrations plasmatiques de vasopressine.

Résultats : Un volontaire a décidé de se retirer, car il a manifesté de l'acathisie après avoir reçu le métoclopramide. Pendant les deux premières heures après l'apomorphine, huit volontaires ont vomi après avoir reçu la bêtaméthasone et le placebo. Un volontaire n'a pas eu que des nausées. Aucun n'a vomi après avoir reçu le métoclopramide $(P<0,01$ vs bêtaméthasone et placebo). Le score maximal à l'EVA pour les nausées a été significativement plus élevé après la bêtaméthasone et le placebo comparés au métoclopramide $(P<0,01)$. Les niveaux de vasopressine se sont élevés après la bêtaméthasone et le placebo, mais non chez les volontaires prétraités avec le métoclopramide.

Conclusion: La bêtaméthasone ne peut prévenir les nausées, les vomissements et l'augmentation de vasopressine induits par l'apomorphine, tandis que le métoclopramide empêche les vomissements induits par l'apomorphine. Notre étude montre que la bêtaméthasone n'a pas d'effets antagonistes sur la dopamine.

From the Departments of Anesthesiology and Intensive Care, Karlstad Central Hospital, ${ }^{*}$ Karlstad; and the Örebro University Hospital, $†$ Örebro, Sweden.

Address correspondence to: Dr. Magnus Wattwil, Department of Anesthesiology and Intensive Care, Örebro University Hospital, 70185

Örebro, Sweden. Phone: +46 1960210 00; Fax: +46 191274 79; E-mail: magnus.wattwil@orebroll.se

Accepted for publication July 19, 2005.

Revision accepted October 18, 2005.

Competing interests: None declared.

The study was supported by grants from Örebro County Council Research Committee. 


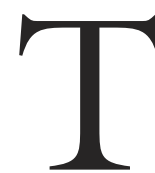

HE incidence of chemotherapy-induced nausea and vomiting and the incidence of postoperative nausea and vomiting (PONV) are reduced in patients receiving prophylaxis with corticosteroids, alone or in combination with other antiemetics. ${ }^{1-3}$ Mainly dexamethasone and, to a lesser extent, betamethasone have been used. ${ }^{3,4}$ The rank order of antiemetic activity of the glucocorticoids is remarkably similar to their known rank order of anti-inflammatory potency, where dexamethasone and betamethasone are approximately equipotent but more potent than methylprednisolone and hydrocortisone respectively. ${ }^{5}$ However, the mechanism of the antiemetic actions of corticosteroids is not known. It has been demonstrated in patients undergoing chemotherapy treatment that blood cortisol levels are reduced by cytotoxic drugs ${ }^{6}$ and that patients with low urinary excretion of cortisol before treatment have a higher incidence of chemotherapy-induced nausea. ${ }^{7}$

The chemoreceptor trigger zone (CTZ) in the area postrema is rich in opioid, dopamine and 5$\mathrm{HT}_{3}$-receptors, and antagonism of these receptors is a primary mechanism of many drugs used to treat PONV. Apomorphine is a dopamine $\mathrm{D}_{2}$-receptor agonist that acts at the level of the CTZ in the area postrema of the medulla. It has been used to empty the stomach before general anesthesia ${ }^{8}$ and it has also been used both in volunteers and in animals when testing antiemetic compounds. ${ }^{9}$ Apomorphine is rapidly absorbed after $s c$ injection and has a clinical effect within ten minutes. The elimination half-life is about $30 \mathrm{~min}^{10,11}$ The antidiuretic hormone arginine vasopressin is released during apomorphine-induced emesis. Metoclopramide is a procaine amide derivate and a benzamide prokinetic agent with dual sites of action, blocking $\mathrm{D}_{2}$-receptors both in the CTZ and the gastrointestinal tract. It has been previously demonstrated that metoclopramide prevents the effects of apomorphine. ${ }^{9}$

The antidopaminergic effects of corticosteroids have not been evaluated before. Therefore the purpose of this study in volunteers was to evaluate if a corticosteroid, betamethasone, can influence apomorphine-induced nausea and vomiting and abolish the increase of vasopressin in plasma induced by apomorphine. Metoclopramide, a dopamine-antagonist, was used as a control substance.

\section{Methods}

The study was carried out on ten healthy, non-smoking volunteers (six males and four females), mean age 21.7 (19-27) yr and mean weight $69.4(53-84) \mathrm{kg}$. The protocol was approved by the Ethics Committee of the
Örebro County Council and the volunteers received verbal and written information and entered the study after giving written informed consent. None of them was taking any medication and none had a history of gastrointestinal symptoms. The study was randomized, double-blinded, cross-over and placebo-controlled. All volunteers were studied on three occasions separated by at least one week. They were randomly allocated to receive pretreatment with betamethasone (Betapred, Swedish Orphan, Stockholm, Sweden) $8 \mathrm{mg}$ iv, metoclopramide (Primperan, Sanofi-Synthelabo, Bromma, Sweden) $10 \mathrm{mg} i v$, or normal saline $2 \mathrm{~mL}$ as a placebo on the three different occasions, 15 min before $s c$ administration of apomorphine. The order of administration was separately randomized for each volunteer. According to our protocol the intention was to give 50 $\mu \mathrm{g} \cdot \mathrm{kg}^{-1} s c$ apomorphine. This was done in the first two volunteers on their first study occasion (pretreatment betamethasone and metoclopramide). The volunteer who received betamethasone as pretreatment reacted with extreme paleness and drowsiness. Thereafter the dose was reduced for safety reasons to $30 \mu \mathrm{g} \cdot \mathrm{kg}^{-1} s c$. The two volunteers who received $50 \mu \mathrm{g} \cdot \mathrm{kg}^{-1} s c$ on their first occasion and $30 \mu \mathrm{g} \cdot \mathrm{kg}^{-1} \mathrm{sc}$ on the other two occasions are included in the study. The study drug (betamethasone, metoclopramide or saline) was administered by a nurse in our department who was not involved in the study in any other way. She received the randomization envelope and gave the drug written on the paper in this envelope. On all three occasions the syringe contained $2 \mathrm{~mL}$. On each occasion the volunteers had fasted for at least four hours. During the study period they received an infusion of $2.5 \%$ glucose $3 \mathrm{~mL} \cdot \mathrm{kg}^{-1} \cdot \mathrm{hr}^{-1}$. After administration of apomorphine, episodes of vomiting were recorded and the intensity of nausea was estimated by the subjects on a visual analogue scale (VAS), (0-10 $\mathrm{cm} ; 0=$ no nausea and $10=$ maximal nausea $)$ every ten minutes for two hours.

Intravenous blood samples for analysis of plasma concentration of arginine vasopressin were taken before administration of the study drug, before apomorphine, and then every five minutes for the next $30 \mathrm{~min}$. The study was concluded two hours after the administration of apomorphine. Throughout the study the volunteers were monitored using an electrocardiogram, pulse oximeter, non-invasive blood pressure monitor and recording of respiratory rate.

Vasopressin concentration was determined using a competitive radioimmunoassay (Nicholas Institute Diagnostics, San Juan Capistrano, CA, USA) according to the manufacturer's instructions. The coefficient of variation is $11.3 \%$ at a concentration of $6.5 \mathrm{ng} \cdot \mathrm{L}^{-1}$ and the sensitivity of the method as defined by the 
TABLE

\begin{tabular}{lll}
\hline Betamethasone & Placebo & Metoclopramide \\
\hline $6.3 \pm 1.9$ & $5.9 \pm 3.1$ & $0.6 \pm 1.0^{*}$ \\
\hline
\end{tabular}

The maximum visual analogue scale of nausea (mean \pm standard deviation) zero to two hours after $s c$ administration of apomorphine and pretreatment with betamethasone, metoclopramide or placebo $15 \mathrm{~min}$ before apomorphine $\left({ }^{*} P<0.01\right.$ compared both to betamethasone and placebo).

lowest calibrator is $2.2 \mathrm{ng} \cdot \mathrm{L}^{-1}$. Blood was drawn into cold ethylenediaminetetraacetic tubes and centrifuged at $+4^{\circ} \mathrm{C}$ within one hour of collection before being stored at $-20^{\circ} \mathrm{C}$ until the time of analysis.

\section{Statistics}

The results are given as means \pm standard deviation. Analysis of variance was used for statistical analysis of the results, followed by a paired $t$ test with Bonferroni's correction. Mc Nemar's test was used for comparison of the number of volunteers vomiting. A $P$ value $<0.05$ was considered statistically significant.

\section{Results}

Ten volunteers were scheduled for the study, but one decided to withdraw on the first study occasion, as he experienced akathisia immediately after receiving metoclopramide. The other nine volunteers completed the entire study.

During the first two hours after apomorphine eight of nine volunteers vomited both after betamethasone and after placebo, but one volunteer did not vomit after either betamethasone or placebo However, this volunteer experienced nausea, and his maximum VAS for nausea was 7.4 after placebo, 6.3 after betamethasone and 0 after metoclopramide. None of the volunteers vomited after metoclopramide $(P<0.01$ vs betamethasone and placebo). The maximum VAS and VAS over time for nausea were significantly higher after betamethasone and placebo compared to metoclopramide (Table, Figure 1). There were no statistically significant differences in the number of volunteers who vomited, or in the maximum VAS and VAS over time for nausea between betamethasone and placebo.

Of those two volunteers who received $50 \mu \mathrm{g} \cdot \mathrm{kg}^{-1}$ of apomorphine, the one who was pretreated with betamethasone vomited, but the one who was pretreated with metoclopramide did not. The maximum VAS of nausea was 9.2 for the volunteer who was given betamethasone as pretreatment, and 2.8 for the volunteer who received metoclopramide.

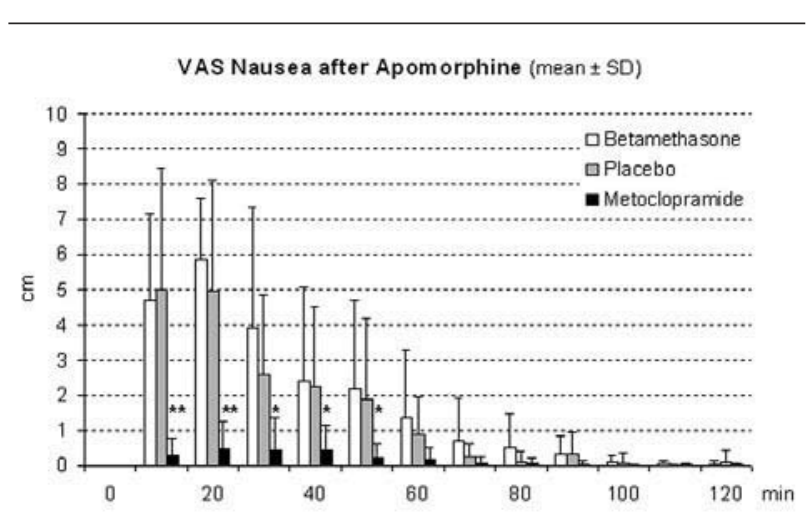

FIGURE 1 Visual analogue scale nausea over time (mean \pm SD) after $s c$ administration of apomorphine and pretreatment with betamethasone, metoclopramide or placebo 15 min before apomorphine $\left({ }^{*} P<0.05,{ }^{*} P<0.01\right.$, metoclopramide compared both to betamethasone and placebo).

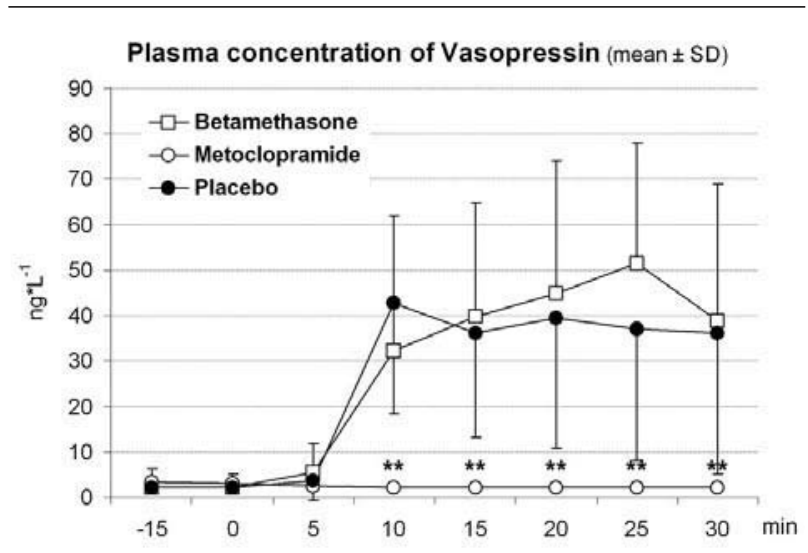

FIGURE 2 Plasma concentrations of vasopressin (mean \pm SD) after $s c$ administration of apomorphine and pretreatment with betamethasone, metoclopramide or placebo 15 min before apomorphine $\left({ }^{*} P<0.01\right.$, metoclopramide compared both to betamethasone and placebo).

Plasma vasopressin concentrations increased after betamethasone and placebo, but no increase was observed in any volunteer after pretreatment with metoclopramide (Figure 2).

Blood pressure, heart rate and respiratory rate remained within normal values except during the vomiting episodes. However, artefact created difficulty in vital sign recording when patients vomited, although both blood pressure and heart rate decreased transiently during these episodes. 


\section{Discussion}

In this study apomorphine, which acts on receptors in the CTZ, was used to induce nausea and vomiting in volunteers. Apomorphine is a dopamine $\mathrm{D}_{2}$-receptor agonist and this was supported by the results in our study, as the volunteers did not experience nausea and did not vomit after pretreatment with the $\mathrm{D}_{2}$-receptor antagonist metoclopramide. The effects of apomorphine started within ten minutes and the duration was short, confirming results from previous studies. ${ }^{10,11}$ Betamethasone $8 \mathrm{mg}$ iv could not abolish the apomorphine-induced emesis, and consequently, given 15 min before apomorphine, does not demonstrate dopamine-antagonistic effects.

The genesis of PONV is multifactorial, so corticosteroids probably interact with receptors other than the dopamine receptors. However, it can be argued that the apomorphine stimulus is much greater than dopamine-induced PONV, and that betamethasone could have been administered earlier. Although the effects of corticosteroids are not immediate, the onset time of these drugs is not clearly established. For prophylaxis of PONV it has been shown that dexamethasone given before the induction of anesthesia is more effective than its administration at the end of anesthesia. ${ }^{12}$ However, non-genomic steroid effects have been demonstrated recently, and these effects are rapid and likely to be transmitted by specific membrane receptors. ${ }^{13}$ In a recently published study it was shown that the analgesic onset time of methylprednisolone is very short, with pain relief after nine minutes. ${ }^{14}$ Several studies have shown that corticosteroids administered alone and in combination with other antiemetics reduce the incidence of PONV and chemotherapy-induced nausea. ${ }^{2,4}$

The combination of dexamethasone and a 5$\mathrm{HT}_{3}$-antagonist is recommended for prophylaxis in chemotherapy treatment, and is also frequently used for prophylaxis of PONV. The glucocorticoid dexamethasone has been used in most clinical studies, but in our country dexamethasone is no longer available. Therefore another glucocorticoid, betamethasone, was selected. Betamethasone seems to have prophylactic effects against PONV and chemotherapy-induced nausea that are similar to those of dexamethasone. ${ }^{3,4}$ Betamethasone and dexamethasone are almost equipotent (1:1.2), so the dose of betamethasone in our study was deemed appropriate. In the present study we could not demonstrate any dopamine antagonistic effects of betamethasone, and in a previous study we also showed that betamethasone does not abolish serotonin-induced nausea and vomiting. ${ }^{15}$

The role of metoclopramide as a prophylaxis for PONV has been previously questioned, and in a review paper by Henzi et al. it was concluded that "metoclopramide, although used as an antiemetic for almost 40 years in the prevention of PONV, has no clinically relevant antiemetic effect and a continuous use of metoclopramide in the dose ranges tested in these studies is inadequate". ${ }^{16}$ In the present study, pretreatment with metoclopramide, $10 \mathrm{mg} i v$, prevented nausea and vomiting induced by the $\mathrm{D}_{2}$-receptor agonist apomorphine. In addition, metoclopramide blocked the increase of vasopressin in plasma induced by apomorphine, and no other side effects of apomorphine such as drowsiness and paleness were observed after pretreatment with metoclopramide. If indeed metoclopramide does not have any clinical effect on PONV, then dopamine-induced nausea and vomiting is probably not what is affected. When volunteers were pretreated with betamethasone and placebo, the plasma concentrations of vasopressin were many times higher. However, the increase in serum vasopressin is probably not caused by nausea, as it was shown in an experimental study in volunteers that apomorphine, but not ipecacuanha, increased the plasma concentration of vasopressin. ${ }^{17}$ Ipecacuanha releases serotonin, so it seems that serotonin-induced nausea and vomiting is not accompanied by an increase of vasopressin.

This study had several limitations. First, apomorphine is a potent drug, and all volunteers who were not pretreated with metoclopramide had strong reactions, with paleness, drowsiness and decreased blood pressure and heart rate during the vomiting episodes. The first two volunteers received $50 \mu \mathrm{g} \cdot \mathrm{kg}^{-1}$ of apomorphine on their first study occasion, but because of the reaction in one subject we reduced the dose to $30 \mu \mathrm{g} \cdot \mathrm{kg}^{-1} s c$ for all volunteers. These two volunteers are included in the study as their nausea, vomiting and vasopressin reactions did not differ from the other volunteers with the same pretreatment. In a previous study by our group, we reported two cases with extreme bradycardia after iv apomorphine. ${ }^{18}$ Respiratory depression, acute circulatory failure, coma and even death have been reported after apomorphine, so it is important to monitor volunteers/patients and adjust the dose according to body weight, age and physical status. Secondly, one volunteer withdrew from the study because he experienced akathisia after metoclopramide. This effect of metoclopramide has been reported previously. ${ }^{19}$ Finally, the number of volunteers was small in the present study. No power calculation was performed, as no similar studies have been done previously. However, the crossover study design addresses in part, the potential confounding issue of inter-patient variability. The results suggest it would be very unlikely to demonstrate a differ- 
ence between betamethasone and placebo even with a much larger sample size, so a futility analysis was considered unnecessary.

In conclusion, this study conducted in volunteers, shows that betamethasone does not prevent nausea, vomiting and an increase of vasopressin induced by apomorphine, whereas metoclopramide prevents these effects. As apomorphine is a dopamine-agonist, our work suggests that betamethasone does not have dopamine-antagonistic effects.

\section{References}

1 McHenzie R, Tantisira B, Karambelkar DJ, Riley TJ, Abdelhady $H$. Comparison of ondansetron with ondansetron plus dexamethasone in the prevention of postoperative nausea and vomiting. Anesth Analg 1994; 79: 961-4.

2 Wattwil M, Thörn SE, Lövqvist Å, Wattwil L, Gupta A, Liljegren $G$. Dexamethasone is as effective as ondansetron for the prevention of postoperative nausea and vomiting following breast surgery. Acta Anaesthesiol Scand 2003; 47: 823-7.

3 Sorbe B, Hallen C, Skare NG, Underskog I. Betamethasone-dixyrazine combination versus highdose metoclopramide as antiemetic treatment in doxorubicin and cisplatin chemotherapy. Radiother Oncol 1989; 15: 161-7.

4 Aasboe V, Raeder JC, Groegaard B. Betamethasone reduces postoperative pain and nausea after ambulatory surgery. Anesth Analg 1998; 87: 319-23.

5 Tasia SW, Chan SW, Rudd JA, Yeung JH. Action of glucocorticoids to antagonise cisplatin-induced acute and delayed emesis in the ferret. Eur J Pharmacol 2001; 417: 231-7.

6 Morrow GR, Hickok JT, Andrews PL, Stern RM. Reduction in serum cortisol after platinum based chemotherapy for cancer: a role for the HPA axis in treatment-related nausea? Psychophysiology 2002; 39: 491-5.

7 Fredrikson M, Hursti T, Fürst CJ, et al. Nausea in cancer chemotherapy is inversely related to urinary cortisol excretion. Br J Cancer 1992; 65: 779-80.

8 Holdsworth JD, Furness RM, Roulston RG. A comparison of apomorphine and stomach tubes for emptying the stomach before general anaesthesia in obstetrics. $\mathrm{Br}$ J Anaesth 1974; 46: 526-9.

9 Proctor JD, Chremos AN, Evans EF, Wasserman AJ. An apomorphine-induced vomiting model for antiemetic studies in man. J Clin Pharmacol 1978; 18: 95-9.

10 LeWitt PA. Subcutaneously administered apomorphine: pharmacokinetics and metabolism. Neurology 2004; 62(Suppl 4): S8-11.

11 Sam E, Jeanjean AP, Maloteaux JM, Verbeke N.
Apomorphine pharmacokinetics in parkinsonism after intranasal and subcutaneous application. Eur J Drug Metab Pharmacokinet 1995; 20: 27-33.

12 Wang JJ, Ho ST, Tzeng JI, Tang CS. The effect of timing of dexamethasone administration on its efficacy as a prophylactic antiemetic for postoperative nausea and vomiting. Anesth Analg 2000; 91: 136-9.

13 Gerdes D, Christ M, Haseroth K, Notzon A, Falkenstein $E$, Webling $M$. Nongenomic actions of steroids -from the laboratory to clinical implications. J Pediatr Endocrinol Metab 2000; 13: 853-78.

14 Romundstad L, Breivik H, Niemi G, Helle A, Stubhang $A$. Methylprednisolone intravenously $\mathrm{l}$ day after surgery has sustained analgesic and opioid-sparing effects. Acta Anaesthesiol Scand 2004; 48: 1223-31.

15 Axelsson P, Thörn SE, Wattwil M. Betamethasone does not prevent nausea and vomiting induced by ipecacuanha. Acta Anaesthesiol Scand 2004; 48: 1283-6.

16 Henzi I, Walder B, Tramèr MR. Metoclopramide in the prevention of postoperative nausea and vomiting: a quantitative systematic review of randomized, placebocontrolled studies. Br J Anaesth 1999; 83: 761-71.

17 Nussey SS, Hawthorn J, Page SR, Ang VT, Jenkins JS. Responses of plasma oxytocin and arginine vasopressin to nausea induced by apomorphine and ipecacuanha. Clin Endocrinol 1988; 28: 297-304.

18 Hvarfner A, Hammas B, Thörn SE, Wattwil M. The influence of propofol on vomiting induced by apomorphine. Anesth Analg 1995; 80: 967-9.

19 LaGorio J, Thompson VA, Sternberg D, Dorje P. Akathisia and anesthesia: refusal of surgery after the administration of metoclopramide. Anesth Analg 1998; 87: 224-7. 